\title{
Economic evaluations
}

\section{Évaluations économiques}

$\mathrm{T}_{3}^{\mathrm{h}}$ he present issue of the Canadian Respiratory Journal contains two papers dealing with cost evaluations $(1,2)$. Both involve the evaluation of previously published datasets, and, appropriately, both are specific to the Canadian situation. Both use methods of measuring cost that may seem simple, or at least comprehensible, but are, in fact, the kind of thing that requires special expertise, ie, cannot be done by amateurs. Therefore, it is not a coincidence that the lead authors of both papers have their primary degrees in Pharmacy, where they pre-

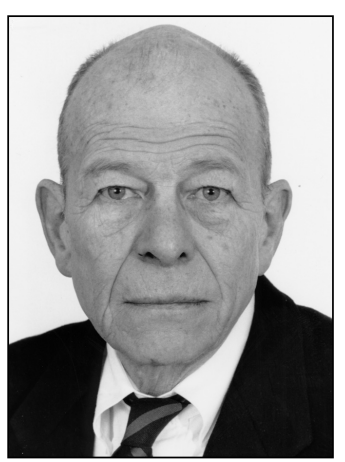

Nick R Anthonisen sumably are taught this kind of thing. Fortunately, the Canadian Respiratory Journal also has access to an expert in this area, Dr Andre Lamy, a surgeon (!) from Hamilton, who regularly and graciously reviews this type of study. His contributions are greatly appreciated and it should be noted that he did not review this editorial and cannot be held responsible for it.

The first paper reports Canadian costs for alternative therapies of asthma tested in an international trial sponsored by a member of Big Pharma (1). Although Canadian patients were included in the trial, the whole dataset (more than 2000 patients) was used for the analysis (3), with Canadian costs attached. The evaluation was very thorough. Drug costs were of course measured, as were care costs such as physician and emergency room visits, other health care visits, hospitalizations and losses of wages by both patients and their caregivers. I cannot think of anything that this study might have omitted, and it is hard to argue with the monetary values assigned to each. The study set out to test whether a regimen of a combined budesonideformoterol inhaler, used as both maintenance and rescue therapy, was as effective and less costly than a fixed dose combined fluticasone-salmeterol inhaler used as maintenance with additional salbutamol for rescue purposes. Combination inhalers are expensive, so that both treatment groups had substantial drug costs. However, they were somewhat less in the budesonide-formoterol group, although this group did not use the relatively cheap salbutamol. Further, there were fewer exacerbations in the former group, and because these are the chief cost-drivers, the difference increased when all costs were considered. My interpretation of these results is that budesonide-formoterol is probably a better rescue agent than salbutamol, presumably because its use increases the intake of inhaled steroids, and that variable dose therapy dictated by the patient is likely to be better than fixed-dose therapy. The latter is the more important point, I think. Intelligent self-management pharmacie, domaine où l'on enseigne, je suppose, ce genre de choses. Heureusement, l'équipe du Journal canadien de pneumologie peut également compter sur les services d'un expert en la matière, le Dr André Lamy, chirurgien (!) de Hamilton, qui examine régulièrement et gracieusement ce genre d'étude. Sa contribution est grandement appréciée, et je tiens à préciser qu'il n’a pas passé en revue le présent éditorial; aussi ne peut-il être tenu responsable de son contenu.

Le premier article fait état du coût de différents traitements de l'asthme au Canada, examinés dans un essai international, commandité par un membre de Big Pharma (1). Bien que des sujets canadiens aient participé à l'essai, l'ensemble complet de données (plus de 2000 sujets) a été utilisé pour réaliser l'analyse (3), à laquelle on a rattaché les coûts au Canada. L'évaluation était exhaustive. Évidemment, on a tenu compte du coût des médicaments ainsi que du coût des soins, notamment des consultations médicales et des consultations à l'urgence, d'autres soins de santé, des hospitalisations et des pertes de revenu des patients et des aidants. Je ne crois pas que certains aspects aient été négligés dans l'étude, et il est difficile de remettre en question la valeur pécuniaire rattachée à chacun des éléments. Leétude visait à vérifier si l'association de budésonide et de formotérol en aérosol, utilisée tant comme traitement d'entretien que comme traitement de rattrapage, était aussi efficace et moins coûteuse que l'association à dose fixe de fluticasone et de salmétérol en aérosol, utilisée en traitement d'entretien, complétée par la prise salbutamol en traitement de rattrapage. Les inhalateurs de médicaments en association coûtent cher, donc le coût des médicaments était élevé dans les deux groupes de traitement. Cependant, il l'était un peu moins dans le groupe de traitement budésonide-formotérol, bien qu'on n'ait pas fait usage de salbutamol, qui est relativement moins cher. De plus, on a noté un peu moins d'exacerbations dans le premier groupe que dans le second, et, comme il s'agit tous d'inducteurs de coût, l'écart augmente lorsqu'on tient compte de tous les coûts. Mon interprétation des résultats est que l'association budésonideformotérol est probablement un meilleur traitement de rattrapage que le salbutamol, sans doute parce que son usage augmente la prise de corticostéroïdes en aérosol et que le traitement à dose 
is the best management of asthma or any other chronic disease, and prescriptions and physicians that encourage this behaviour are most likely to be successful. One could regard the 'fixed dose' arm of this trial as a bit of a straw man, because it denied the patients this opportunity to some extent. It should also be noted that we all have patients who seem to be incapable of intelligent self-management, and that in such people fixed-dose regimens are eminently sensible.

The second study (2) is much more restricted, involving the costs of diagnosing occupational asthma. It was authored by the groups most active in this area in Canada, which have been world leaders in this diagnosis. Previous techniques for making this diagnosis have largely involved monitoring peak expiratory flow through working and nonworking days, as well as specific inhalation challenges with suspected inciting agents. The former technique is relatively cheap, but is nonspecific and very dependent on patient cooperation. The second is difficult and expensive, and, in fact, is carried out as a clinical routine in only a few Canadian centres, including those of the authors. It is, however, the gold standard. Recently, this group has examined the utility of examining induced sputum for eosinophils, and noted that people with occupational asthma had increases of $1 \%$ or more in sputum eosinophilia at work (4). In the current study, they look at the costs involved and the results obtained as compared with the gold standard. Sputum examination costs were estimated to be roughly comparable with those of peak expiratory flow monitoring. A large number of other factors were considered but the take home message is clear. Peak expiratory flow monitoring is not very good, making the correct diagnosis in approximately $50 \%$ of the cases. Sputum examination was substantially better, leading to a correct diagnosis in $72 \%$ of cases. Presumably, this was because it was less dependent on patient cooperation. So the message is that one is better off doing sputum examinations than peak expiratory flow monitoring, in terms of cost-effectiveness, that is, dollars spent for a correct conclusion. There are several caveats. First, sputum eosinophilia is not necessarily an easy thing to do, and comparable cost-effectiveness is dependent on doing it as well as the authors, the world experts. Second, is a $72 \%$ success rate adequate for a test of occupational asthma? It would be easy to argue that it is not, and that everyone should have specific inhalation challenge for the diagnosis, but this is nearly impossible in any place but Quebec and Ontario. We are left with a conundrum. I suspect that in many parts of Canada the diagnosis is made on history alone, often giving the benefit of the doubt to the patient. This is, I believe, defensible, but it would probably be better if more centres learned to measure sputum eosinophilia.

Nick R Anthonisen MD

Editor-in-Chief, Canadian Respiratory Journal variable, commandé par le patient est probablement meilleur que le traitement à dose fixe. Ce dernier point est vraisemblablement le plus important, à mon avis. La prise en charge «intelligente » est le meilleur traitement de l'asthme ou de toute autre maladie chronique, et les médecins et les prescripteurs qui encouragent ce type de comportement sont plus susceptibles de réussir. On pourrait considérer le groupe de traitement à dose fixe dans l'essai un peu comme un groupe bidon du fait qu'il prive, en quelque sorte, les sujets de cette possibilité. Il convient également de souligner que nous avons tous des patients qui semblent incapables de se prendre en charge de façon intelligente et que le traitement à dose fixe est alors la formule à privilégier.

La deuxième étude (2) est beaucoup plus limitée du fait qu'elle porte sur le coût du diagnostic de l'asthme d'origine professionnelle. L'étude a été signée par les groupes les plus actifs dans le domaine, au Canada, chefs de file mondiaux dans ce type de diagnostic. La pose du diagnostic repose en grande partie sur la surveillance du débit expiratoire maximal durant les journées de travail et les journées de congé ainsi que sur les tests de provocation respiratoires par des agents supposés responsables. La première technique coûte relativement peu cher, mais elle est non spécifique et fortement tributaire de la collaboration du patient; la seconde est difficile et coûteuse, et, en fait, elle n'est réalisée de façon systématique que dans quelques centres de traitement de l'asthme au Canada, dont celui des auteurs; il s'agit là pourtant de l'examen de référence. Dernièrement, le groupe s'est penché sur l'utilité de l'examen des expectorations provoquées à la recherche d'éosinophiles et il a constaté que l'éosinophilie dans les expectorations augmentait de un pour cent ou plus chez les patients souffrant d'asthme professionnel lorsqu'ils étaient dans leur milieu de travail (4). Dans l'étude en question, les auteurs se sont intéressés aux coûts et aux résultats obtenus par rapport à ceux de l'examen de référence. Ils ont estimé que le coût de l'examen des expectorations était à peu près le même que celui de la surveillance du débit expiratoire maximal. Un grand nombre d'autres facteurs ont été pris en considération, mais le message clé à retenir ne laisse aucune ambiguité : la surveillance du débit expiratoire maximal n'est pas une très bonne mesure, qui ne permet la pose du bon diagnostic que dans $50 \%$ des cas environ. L'examen des expectorations s'est révélé de beaucoup supérieur; en effet, il a permis la pose du bon diagnostic dans $72 \%$ des cas, sans doute parce que le test dépend beaucoup moins de la collaboration du patient. Bref, ce qu'il faut retenir du message, c'est qu'il est préférable de procéder à l'examen des expectorations plutôt que de surveiller le débit expiratoire maximal pour poser le diagnostic, du point de vue de la rentabilité, c'est-à-dire de l'argent dépensé pour arriver à la bonne conclusion. Cependant, plusieurs mises en garde s'imposent. Premièrement, la mesure de l'éosinophilie dans les expectorations n'est pas nécessairement un examen facile à réaliser, et une rentabilité comparable dépend et du savoir-faire et des auteurs, experts mondiaux. Deuxièmement, est-ce qu'un taux de réussite de $72 \%$ est satisfaisant pour un test de diagnostic de l'asthme professionnel? On pourrait facilement répondre non et arguer que tous devraient subir un test de provocation respiratoire par certains agents en vue de la pose du diagnostic, mais cela est pratiquement impossible partout, sauf au Québec et en Ontario. Nous voilà donc devant un problème. Je suppose que, dans bien des régions du Canada, on pose le diagnostic à partir des seuls éléments d'anamnèse, laissant souvent 


\section{REFERENCES}

1. Miller E, Sears MR, McIvor A, Liovas A. Canadian economic evaluation of budesonide/formoerol as maintenance and reliever treatment in patients with moderate to severe asthma. Can Respir J 2007;14:269-75.

2. Kennedy WA, Girard F, Chaboillez S, et al. Cost-effectiveness of various diagnostic approaches for occupational asthma. Can Respir J 2007;14:276-80.

3. Vogelmeier C, D'Urzo A, Pauwels R, et al. Budesonide/formoterol maintenance and reliever therapy: An effective asthma option? Eur Respir J 2005;26:819-28. (Erratum in 2005;26:1191).

4. Girard F, Chaboillez S, Cartier A, et al. An effective strategy for diagnosing occupational asthma: Use of induced sputum. Am J Respir Crit Card Med 2004;170:845-850. le bénéfice du doute aux patients. Cette façon de faire est certes défendable, mais il serait probablement préférable qu'on apprenne, dans plus de centres, à mesurer l'éosinophilie dans les expectorations.

Nick R. Anthonisen, MD Rédacteur en chef $d u$ Journal canadien de pneumologie

\section{RÉFÉRENCES}

1. Miller E, Sears MR, McIvor A, Liovas A. Canadian economic evaluation of budesonide/formoerol as maintenance and reliever treatment in patients with moderate to severe asthma. Can Respir J 2007;14:269-75.

2. Kennedy WA, Girard F, Chaboillez S, et al. Cost-effectiveness of various diagnostic approaches for occupational asthma. Can Respir J 2007; 14:276-80.

3. Vogelmeier C, D'Urzo A, Pauwels R, et al. Budesonide/formoterol maintenance and reliever therapy: An effective asthma option? Eur Respir J 2005;26:819-28. (Erratum in 2005;26:1191).

4. Girard F, Chaboillez S, Cartier A, et al. An effective strategy for diagnosing occupational asthma: Use of induced sputum. Am J Respir Crit Card Med 2004;170:845-850. 


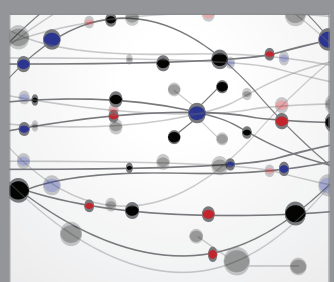

The Scientific World Journal
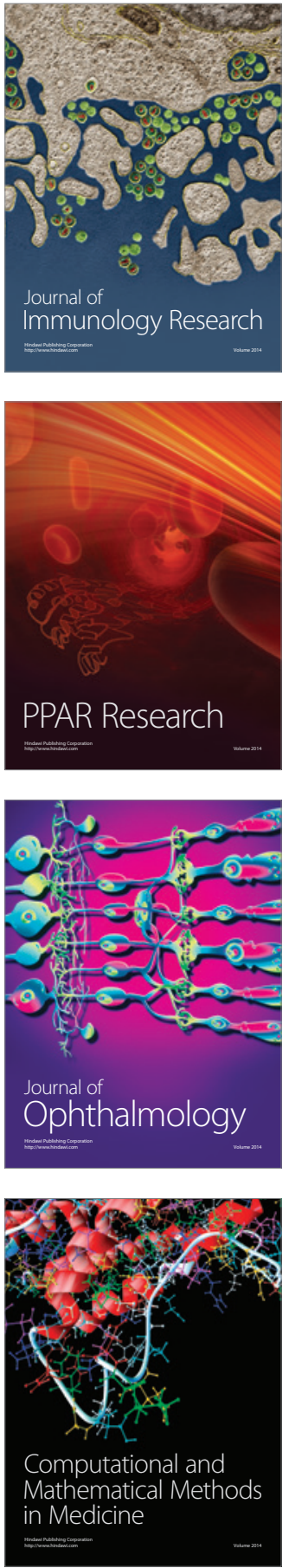

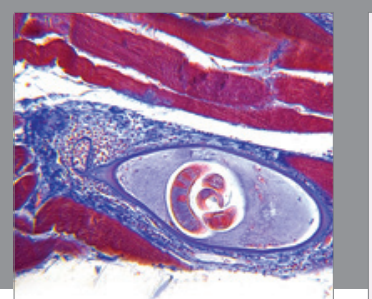

Gastroenterology Research and Practice

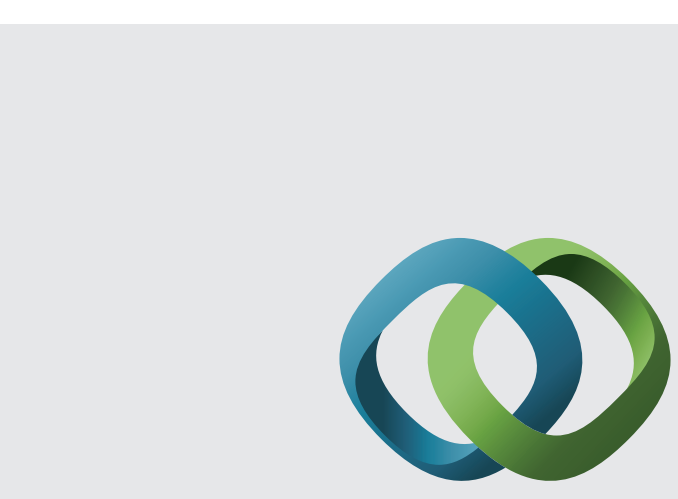

\section{Hindawi}

Submit your manuscripts at

http://www.hindawi.com
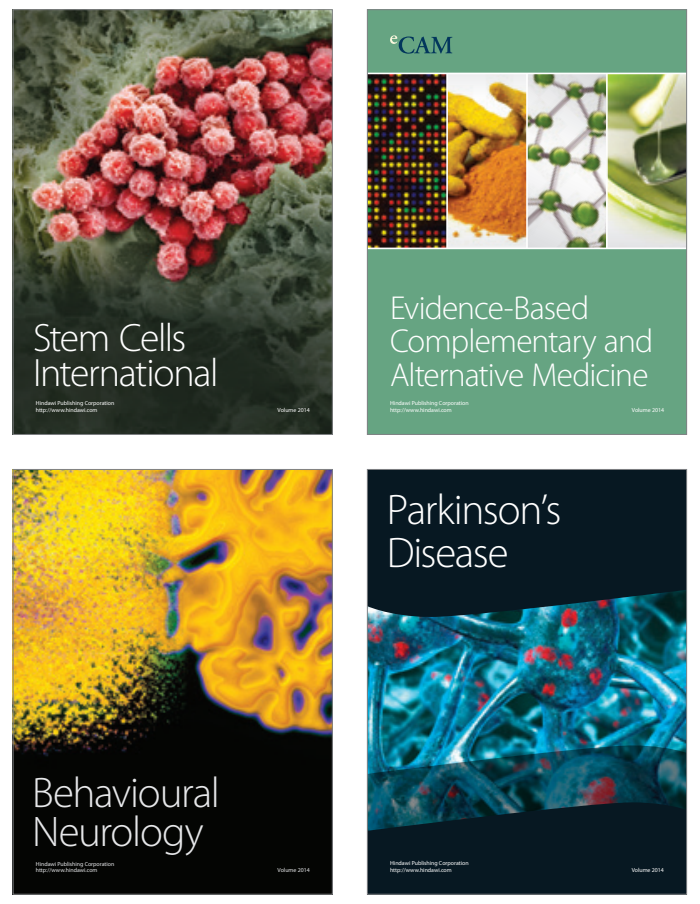
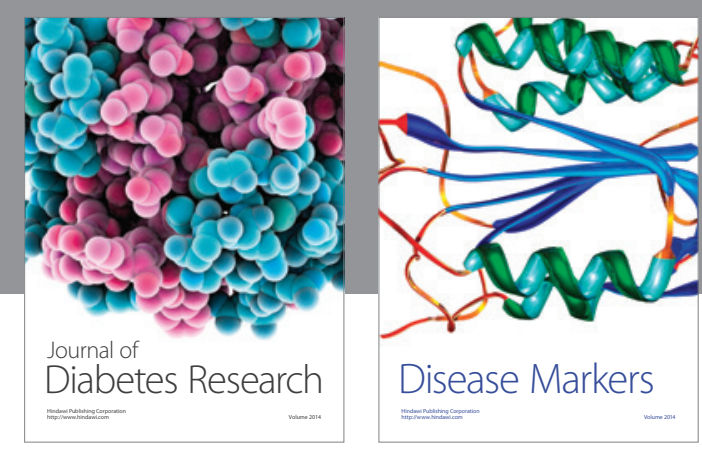

Disease Markers
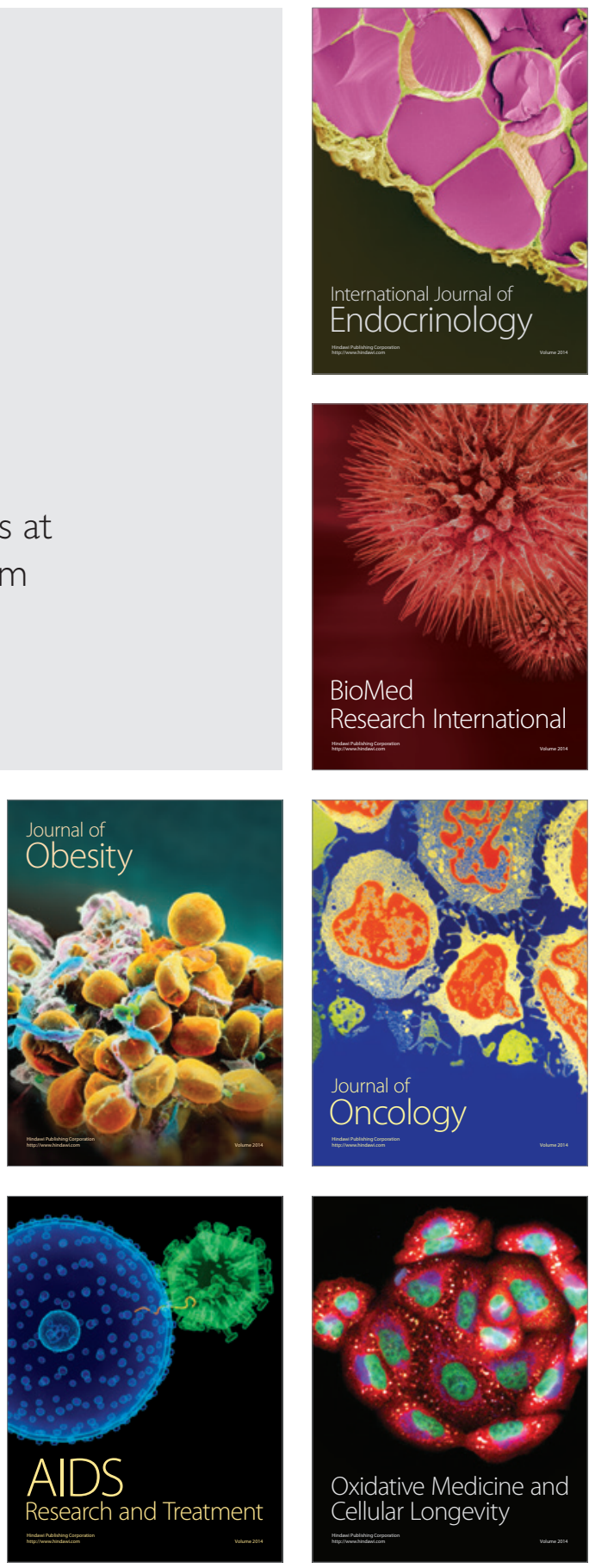